\title{
Corporate Governance dan kinerja keuangan Bank Syariah di Indonesia
}

\author{
Carmidah $^{1^{*}}$, Sukirno ${ }^{2}$
}

1)Institut Agama Islam Negeri Metro, Kota Metro,Indonesia, carmidah@metrouniv.ac.id

${ }^{2)}$ Sekolah Tinggi Ilmu Ekonomi Asholeh Pemalang, Pemalang, Indonesia, sukirnopml@gmail.com

\begin{tabular}{|c|c|}
\hline ARTICLE INFO & A B S T R A C T \\
\hline $\begin{array}{l}\text { Article history: } \\
\text { Received : } 10 \text { Maret } 2021 \\
\text { Received in Revised : } 20 \text { April } 2021 \\
\text { Accepted : } 29 \text { April } 2021 \\
\end{array}$ & \multirow{2}{*}{$\begin{array}{l}\text { Corporate governance consists of a unique set of rules to protect the } \\
\text { interests of company shareholders. Success in implementing } \\
\text { governance is determined by the extent to which the company identifies } \\
\text { optimally in accordance with the conditions of the company concerned, } \\
\text { especially Islamic banks in Indonesia. The purpose of this study is to } \\
\text { prove that good governance can affect the financial performance of } \\
\text { Islamic banks in Indonesia and tries to contribute to the academid } \\
\text { literature by providing evidence that good governance can affect the } \\
\text { financial performance of Islamic banks in Indonesia. This study uses } \\
\text { panel data from } 12 \text { Indonesian Sharia Commercial Banks for the } \\
\text { financial year } 2014 \text { to 2018. The results show that the number of } \\
\text { boards of directors and characteristics of the boards of directors have } \\
\text { a positive effect on financial performance as measured by Return On } \\
\text { Assets (ROA). }\end{array}$} \\
\hline \multirow[t]{2}{*}{$\begin{array}{l}\text { Keywords: } \\
\text { Coorporate } \\
\text { Keuangan }\end{array}$} & \\
\hline & $\begin{array}{l}\text { Tata kelola perusahaan terdiri dari seperangkat aturan unik untul } \\
\text { melindungi kepentingan pemegang saham perusahaan. Keberhasilan } \\
\text { dalam penerapan tata kelola ditentukan oleh sejauh mana perusahaan } \\
\text { mengidentifikasi secara optimal yang sesuai dengan kondis } \\
\text { perusahaan yang bersangkutan khususnya bank syariah di Indonesia. } \\
\text { Tujuan penlitian ini membuktikan bahwa tata kelola yang baik dapat } \\
\text { mempengaruhi kinerja keuangan bank syariah di Indonesia dan } \\
\text { berusaha memberikan kontribusi pada literatur akademik dengan } \\
\text { memberika bukti bahwa tata kelola yang baik dapat mempengaruh } \\
\text { kinerja keuangan bank syariah di indonesia. Penelitian in } \\
\text { menggunakan data panel dari } 12 \text { Bank Umum Syariah Indonesia untuk } \\
\text { tahun pembukuan } 2014 \text { hingga } 2018 . \text { Hasil menunjukkan bahwa jumlah } \\
\text { dewan direksi dan karakteristik dewan direksi berpengaruh positi } \\
\text { terhadap kinerja keuangan yang di ukur dengan Return On Assets } \\
\text { (ROA). }\end{array}$ \\
\hline
\end{tabular}

AKUISISI : Jurnal Akuntansi

Website : http://www.fe.ummetro.ac.id/ejournal/index.php/JA

This is an open access article distributed under the terms of the Creative Commons Attribution 4.0 International License, which permits unrestricted use, distribution, and reproduction in any medium, provided the original work is properly cited.

* Corresponding author. Tel.: +0-000-000-0000 ; fax: +0-000-000-0000.

E-mail address: carmidah@metrouniv.ac.id

Peer review under responsibility of Akuisisi : Accounting Journal. 2477-2984.

http://dx.doi.org/10.24217 


\section{PENDAHULUAN}

Keuangan syariah terutama sektor perbankan syariah telah berkembang pesat di seluruh dunia (Grassa, 2013; Mizushima, 2014; Grassa, 2016; Ullah dan Khanam, 2018). Bahkan perkembangan bank syariah dapat melampauhi bank konvensional (Ullah dan Khanam, 2018). Perkembagan ini tidak hanya di negara-negara dengan populasi Muslim mayoritas, tetapi juga di negara-negara lain di mana Muslim adalah minoritas (Beg, 2016). Begitupun di Indonesia, bank syariah telah berkembang pesat (Juanda, dkk. 2019). Semenjak pertama kali berdiri bank umum syariah tahun 1992 sampai sekarang telah memiliki sejumlah 14 bank umum syariah (SPS, 2019). Nastiti dan Firdaus (2019) memberikan catatan bahwa perkembangan bank umum syariah terbagi dalam tiga dekade. Dekade pertama Tahun 1992 sampai dengan tahun 2001 ditandai dengan lahirnya bank syariah pertama yaitu Bank Muamalat Indonesia dan Bank Syariah Mandiri. Dekade kedua dari tahun 2002 sampai dengan tahun 2011 ada penambahan jumlah bank umum syariah sejumlah 9 bank umum syariah yang beroperasional yaitu Bank Mega Syariah, bank Syariah Bukopin, Bank Panin Syariah, Bank Rakyat Indonesia Syariah (BNI Syariah), Bank Victoria Syariah, Bank Central Asia Syariah, Bank Jabar Banten Syariah, Bank Negara Indoenesia Syariah (BRIS) dan Bank Maybank Syariah. Dekade yang terakhir dari tahun 2012 sampai dengan sekarang ada penambahan jumlah bank umum syariah yaitu tiga bank umum syariah meliputi Bank Tabungan Pensiun Nasional Syariah (BPTPN Syariah), Bank Aceh Syariah dan Bank BPD Nusa Tenggara Barat Syariah.

Ada berbagai alternatif kebijakan pengambilan keputusan dalam mengatasi permasalahan yang dihadapi bank syariah tersebut, salah satunya dengan menerapkan praktik tata kelola perusahaan (corporate governance) yang efisien (Hasan, dkk. 2017). Tata kelola di bank syariah memainkan peran penting dalam memastikan kepercayaan bagi para stakeholder, antara lain pemegang saham, direksi, manajemen, pelanggan, karyawan, kreditor, debitor, lembaga pemerintah, bank, lembaga keuangan dan masyarakat pada umumnya (Younas, dkk. 2018 dan Aziz, dkk. 2019). Ada dua kategori mekanisme tata kelola perusahaan yaitu mekanisme internal misalnya ukuran dewan, independensi dewan dan dewan direksi) dan mekanisme eksternal misalnya kondisi pasar yang kompetitif, pasar untuk tenaga kerja manajerial dan bakat, serta pasar untuk pengendalian perusahaan (Zabri dkk, 2015). Beberapa mekanisme corporate governance dalam penelitian ini menggunakan indikator internal yaitu jumlah dewan direksi, jumlah dewan pengawas syariah, karakteristik dewan direksi dan jumlah rapat dewan direksi.

Valenti, dkk. (2011) mencatat bahwa banyak pengukuran kinerja keuangan telah digunakan dalam literatur tata kelola dan diakui secara umum. Kinerja Keuangan suatu perusahaan dapat digunakan untuk mengukur kesehatan keuangan perusahaan secara keseluruhan selama periode tertentu (Shunu dkk, 2017). Berbagai alat dirancang untuk membantu pengguna menganalisis laporan keuangan, salah satu alat analisis keuangan yang paling populer dan banyak digunakan adalah rasio keuangan (Subramanyam, 2014). Rasio keuangan menyediakan cara yang cepat dan relatif sederhana 
untuk menilai kesehatan keuangan suatu bisnis (Atrill dan McLaney, 2006). ROA yang termasuk dalam kinerja berbasis akuntansi biasa digunakan dalam penelitian terbaru dalam tata kelola perusahaan yang baik (Buchdadi, dkk. 2019) dan menggunakan data akuntansi yang diaudit sehingga memastikan perspektif yang dapat diandalkan tentang kinerja perusahaan (Misra dan Kapil, 2018).

Tata kelola perusahaan banyak dikembangkan dalam penelitian dalam menjelaskan dan memprediksi kinerja keuangan perusahaan, baik kinerja keuangan berbasis akuntansi maupun kinerja keuangan berbasis pasar (Kowalewski, 2016 dan Bhat dan Bhat, 2017). Begitupun tata kelola perusahaan pada bank telah menjadi bidang signifikan yang perlu lebih diperhatikan di tingkat internasional (Buallay, 2019). Berdasarkan landasan teori dan review penelitian terdahulu maka hipotesis dan model penelitian yang dibangun dalam penelitian ini adalah sebagai berikut:

\section{Jumlah Dewan Direksi mempunyai pengaruh positif terhadap kinerja keuangan Bank Umum Syariah}

Bentuk implementasi untuk menjamin penyeimbangan kepentingan manajemen dan pemegang saham adalah dengan adanya penyesuaian jumlah dewan direksi dengan kompleksitas perusahaan dan efektifitas dalam pengambilan keputusan sehingga partisipasi anggota dewan tercapai secara efisien (Iqbal, dkk, 2018). Ukuran dewan direksi yang optimal memberikan dukungan empiris untuk teori keagenan yang menunjukkan bahwa perusahaan secara efektif memberi saran, memantau dan mendisiplinkan manajemen sehingga meningkatkan kinerja perusahaan (Badu dan Appiah). Hal ini diperkuat oleh penelitian yang dilakukan oleh Badu dan Appiah, (2016), Kalsie dan Shrivastav (2016), Shunu, dkk (2017) dan Qadorah, dkk (2018) menunjukkan hasil bahwa ukuran dewan direksi memiliki pengaruh positif dan signifikan terhadap kinerja perusahaan yang diukur dengan ROA. Oleh karena itu, hipotesis dalam penelitian ini adalah :

$\mathrm{H}_{1}=$ Jumlah Dewan Direksi mempunyai pengaruh positif terhadap kinerja keuangan Bank Umum Syariah

\section{Pengaruh Jumlah Dewan Pengawas Syariah Terhadap Kinerja keuangan Bank Syariah}

Semakin berfungsinya Dewan Pengawas Syariah dalam menanamkan kepercayaan masyarakat dengan memastikan kepada konsumen muslim bahwa produk dan layanan keuangan yang ditawarkan oleh perbankan adalah halal dan dapat diterima dari segi perspektif hukum islam, melindungi manajemen dan operasional lembaga keuangan untuk mematuhi prinsip-prinsip islam dalam perumusan kebijakan dan strategi perusahaan maka akan berdampak pada peningkatan kinerja keuangan perusahaan (Aribi.dkk, 2018; Almutairi.dkk, 2017). Jumlah anggota dewan pengawas yang lebih kecil maka akan lebih mudah dikontrol karena memberikan komunikasi yang lebih baik dan lebih efektif dibandingkan dengan jumlah dewan pengawas yang lebih besar (Nomran dkk,2018). Hal ini diperkuat oleh penelitian yang dilakukan oleh Nomran Dan Haron (2018), Darwanto dan Chariri 
(2019) yang menemukan hasil bahwa Dewan Syariah berpengaruh positif terhadap kinerja keuangan bank syariah. Oleh karena itu, hipotesis dalam penelitian ini adalah :

$\mathrm{H}_{2}=$ Jumlah Dewan Pengawas Syariah mempunyai pengaruh positif terhadap kinerja keuangan Bank Umum Syariah

\section{Pengaruh Karakteristik dewan direksi Terhadap Kinerja keuangan Bank Syariah}

Dewan yang memiliki keberagaman gender akan memiliki kinerja keuangan yang lebih baik jika keanekaragaman dapat dimanfaatkan sebagai peran penasehat dan pemantauan yang lebih baik melebihi biaya komunikasi dan konflik antara tingkat manajerial (Farag,2016). Belhaj dan Mateus (2016) menyebutkan bahwa Dewan direksi dengan lebih banyak anggota wanita menghasilkan kinerja bank yang lebih baik. Hal ini diperkuat oleh penelitian yang dilakukan oleh Cardillo dkk, 2020, Dang, dkk (2020) menunjukkan hasil bahwa keberagaman gender berdampak positif terhadap kinerja bank yang diproksikan dengan ROA. Oleh karena itu, hipotesis dalam penelitian ini adalah :

$\mathrm{H}_{3}=$ Karakteristik dewan direksi mempunyai pengaruh positif terhadap kinerja keuangan Bank Umum Syariah

\section{Pengaruh Jumlah Rapat Dewan Terhadap Kinerja keuangan Bank Syariah}

Rapat dewan memiliki peran yang penting sebagai kegiatan monitoring kinerja direksi (Buchdadi dkk, 2019). Melalui frekuensi rapat maka anggota dewan dapat memutuskan masalah operasional melalui diskusi dan terlibat dengan proses pembuatan keputusan satu sama lain sehingga berdampak pada meningkatnya kinerja perusahaan (Daoud dkk, 2016). Ketika intensitas pertemuan rapat dewan lebih banyak maka akan lebih banyak informasi dan pengetahuan terkait kinerja perusahaan (Eluyela, dkk, 2018). Hal ini diperkuat oleh penelitian yang dilakukan oleh Haider dkk (2015), Daoud dkk (2016), Eluyela, dkk (2018) dan Usman (2018) yang menunjukkan Hasil empiris penelitian menunjukkan adanya hubungan positif antara frekuensi rapat dewan dan kinerja perusahaan. Oleh karena itu, hipotesis dalam penelitian ini adalah :

$\mathrm{H}_{4}=$ Jumlah rapat dewan mempunyai pengaruh positif terhadap kinerja keuangan Bank Umum Syariah.

Gambar 1 - Kerangka Model Penelitian

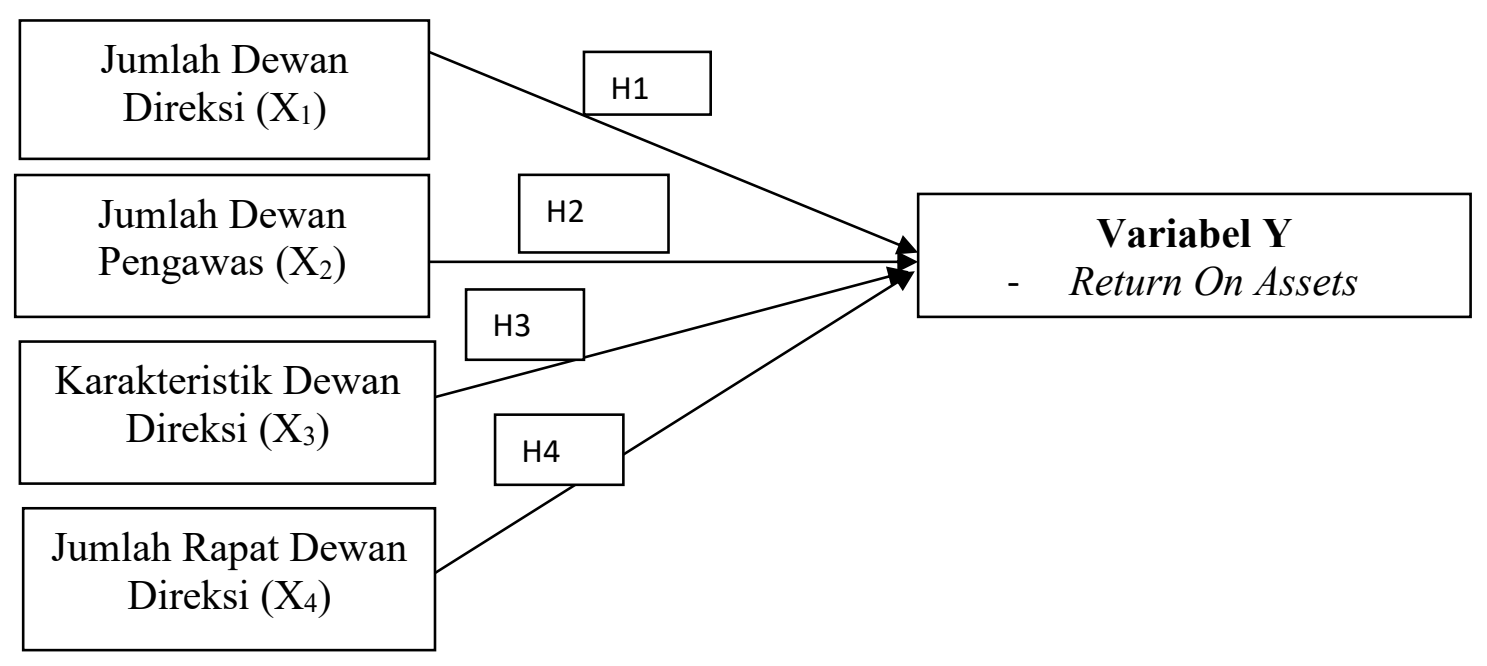




\section{METODOLOGI}

Data yang digunakan dalam penelitian ini adalah data panel yang merupakan gabungan antara data corss section dan times series. Data cross section dalam penelitian ini terdiri dari 12 Bank Umum Syariah dan data time series terdiri dari data Jumlah Dewan Direksi, Jumlah Dewan Pengawas Syariah, Karakteristik dewan direksi dan Jumlah rapat dewan dari tahun 2014 sampai dengan tahun 2018.

Penelitian ini bertujuan untuk membuktikan bahwa tata kelola dapat mempengaruhi kinerja keuangan perbankan syariah yang diproksikan dengan Return On Assets (ROA). Objek penelitian ini adalah Bank Umum Syariah yang melaporkan pelaporan keuangan tahunan dari tahun 2014 sampai dengan 2018. Data dalam penelitian ini menggunakan populasi sebagai data sampel penelitian. Pemilihan sampel menggunakan metode purposive sampling dengan kriteria sebagai berikut:

1) Kategori Bank Umum Syariah

2) Tedaftar pada Otoritas Jasa Keuangan (OJK)

3) Bank Umum Syariah yang melaporkan pelaporan keuangan tahunan dari tahun 2014 sampai dengan 2018.

4) Bank Umum Syariah yang melaporkan pelaporan keuangan tahunan dari tahun 2014 sampai dengan 2018 secara berurutan dan lengkap.

Berdasarkan teknik purposive sampling maka didapatkan sampel sebanyak 12 Bank Umum Syariah disajikan pada tabel 4.1 sebagai berikut:

Tabel 1 - Daftar Sampel Penelitian

\begin{tabular}{|c|l|c|l|}
\hline No & \multicolumn{1}{|c|}{ Nama Bank } & No & \multicolumn{1}{|c|}{ Nama Bank } \\
\hline 1. & Bank Muamalat Indonesia & 7. & Bank Victoria Syariah \\
2. & Bank Syariah Mandiri & 8. & Bank Central Asia Syariah \\
3. & Bank Mega Syariah & 9. & Bank Jawa Barat Syariah \\
4. & Bank Bukopin Syariah & 10. & Bank Negara Indonesia Syariah \\
5. & Bank Panin Syariah & 11. & Maybank Syariah \\
6. & Bank Rakyat Indonesia Syariah & 12 & Bank Tabungan Pensiun Nasional Syariah \\
\hline
\end{tabular}

Sumber : Data skunder yang diolah 2020

Metode analisis data menggunakan analisis Regresi Data Panel. Data panel merupakan data dari hasil pengamatan pada beberapa individu atau (unit cross-sectional) dalam beberapa periode waktu yang berurutan (unit waktu) (Baltagi, 2005). Bentuk umum estimasi model regresi linear tersebut terdiri dari empat variabel independen dan dua variabel dependen, dengan model sebagai berikut:

$$
Y_{i t}=\beta_{0 i t}+\beta_{1 i t} X_{1 i t}+\beta_{2 i t} X_{2 i t}+\beta_{3 i t} X_{3 i t}+\beta_{4 i t} X_{4 i t}+\varepsilon_{i t}
$$

Model tersebut dapat ditransformasikan kedalam persamaan logaritma (Ln), sehingga menjadi bentuk model sebagai berikut :

$$
\mathrm{LnY}_{\mathrm{it}}=\beta_{0 \mathrm{it}}+\beta_{1 \mathrm{it}} \operatorname{LnX}_{1 \mathrm{it}}+\beta_{2 \mathrm{it}} \operatorname{LnX} \mathrm{X}_{2 \mathrm{it}}+\beta_{3 \mathrm{it}} \operatorname{LnX} \mathrm{Xit}_{3 \mathrm{it}}+\beta_{4 \mathrm{it}} \operatorname{LnX} \mathrm{X}_{4 \mathrm{it}}+\varepsilon_{\mathrm{it}}
$$


Sebelum melakukan pengujian regresi data panel, yang perlu diperhatikan adalah pemilihan estimasi model data panel. Pengujian dilakukan untuk menentukan atau memilih salah satu estimasi model terbaik diantara tiga estimasi model yaitu common effectss model, fixed effectss model dan random effectss model (Sriyana, 2014). Adapun tahapan untuk menentukan pemilihan estimasi model data panel, antara lain :

\section{Uji Chow}

Tahap awal pemilihan estimasi model regresi data panel adalah memilih estimasi model regresi data panel antara common effects model dengan fixed effects model (Sriyana, 2014). Pada tahap ini, secara umum menggunakan uji Chow lebih tepat dilakukan (Baltagi, 2005). Uji Chow dilakukan dengan menggunakan uji F dengan tujuan menguji perbedaan antar kelompok (Greene, 2003).

\section{Uji Lagrange multiplier (Uji LM - Uji Breusch-Pagan)}

pengujian dilakukan untuk memilih estimasi model regresi data panel antara common effects model dengan random effects model (Sriyana, 2014; Baltagi, 2005 dan Greene, 2003). Hasil uji Lagrange multiplier atau uji LM digunakan untuk menentukan pilihan estimasi model regresi data panel yang terbaik antara common effects model dengan random effects model (Sriyana, 2014 dan Greene, 2003). Adapun notasi uji LM dengan mengikuti notasi yang digunakan oleh Sriyana (2014) dan Greene (2003), yaitu :

$\mathrm{LM}=\frac{n T}{2(T-1)}\left[\frac{\sum_{i=1}^{n}\left[\sum_{t=1}^{t} e i t\right]}{\sum_{i=1}^{n} \sum_{t=1}^{t} e i t^{2}}-1\right]^{2}=\frac{n T}{2(T-1)}\left[\frac{\sum_{i=1}^{n}(T-\overline{e i})^{2}}{\sum_{i=1}^{n} \sum_{t=1}^{t} e i t^{2}}-1\right]^{2}$

\section{Uji Hausman}

Uji Hausman merupakan uji spesifikasi yang disusun oleh Hausman pada tahun 1978. Uji ini digunakan untuk menguji ortogonalitas dari random effects dan variabel-variabel bebas (greene, 2003). Sriyana (2014) memberikan tambahan bahwa uji Hausman digunakan untuk mengetahui pilihan estimasi model regresi data panel yang lebih baik diantara model LSDV pada pendekatan fixed effects model dan GLS pada pendekatan random effects model. Adapun notasi uji Hausman dengan mengikuti notasi yang digunakan oleh Sriyana (2014), yaitu :

$$
\mathrm{W}=\chi^{2}[K]=\left[\widehat{\beta} \cdot \widehat{\beta}_{G L S}\right] \sum^{-1}\left[\widehat{\beta}-\widehat{\beta}_{G L S}\right]
$$

\section{Pengujian Goodness of Fit Suatu Model Regresi}

Ketepatan dalam membuat estimasi model regresi sampel untuk menaksir nilai aktual dapat diukur dari goodness of fit. Sementara pengukuran goodness of fit secara statistik dapat menggunakan koefisien determinasi, nilai statistik $\mathrm{t}$ dan nilai statistik F (Ghozali dan Ratmono, 2017 dan Gujarati dan porter, 2012). 


\section{Koefisien Determinasi}

Koefisien determinasi merupakan kemampuan model regresi untuk mengukur seberapa baik variabel - variabel independen dapat menjelaskan variasi variabel dependen (Ghozali dan Ratmono, 2017; Gujarati dan Porter, 2012 dan Lind, dkk. 2008). Sementara notasi koefisien determinasi mengikuti notasi yang dinyatakan oleh Sriyana (2014), yaitu :

$$
R^{2}=\frac{E S S}{T S S} \quad R^{2}=1-\frac{R S S}{T S S}
$$

Selain melihat hasil $\mathrm{R}^{2}$, melihat koefisien determinasi dapat menggunakan nilai koefisien determinasi adjusted R-squared. notasi koefisien determinasi adjusted $\mathrm{R}^{2}$ dengan mengikuti model yang dinyatakan oleh Sriyana (2014), yaitu :

$$
\bar{R}^{2}=1-\frac{\left(\sum \hat{e}_{i}^{2}\right) /(n-k)}{\sum\left(Y_{i}-\bar{Y}\right)^{2} /(n-1)}
$$

\section{Uji Signifikansi Individual atau Uji Statistik t}

uji statistik $\mathrm{t}$ pada dasarnya untuk menunjukkan seberapa jauh pengaruh satu variabel independen terhadap variabel dependen dengan menganggap variabel independen lainnya konstan (Ghozali dan Ratmono, 2017 dan Gujarati dan Porter, 2012). Adapun notasi uji statistik t dengan mengikuti notasi yang dinyatakan oleh Ghozali dan Ratmono (2017), yaitu

$$
t=\frac{\beta 1}{\operatorname{se}(\beta 1)}
$$

\section{Uji Signifikansi Simultan atau Uji Statistik F)}

uji ini dilakukan untuk melihat variabel dependen secara linier berhubungan dengan semua variabel independen atau melihat kemampuan variabel independen $(\mathrm{X} 1, \mathrm{X} 2, \ldots .$. dan seterusnya) dalam menjelaskan prilaku variabel dependen Y (Ghozali dan Ratmono, 2017 dan Lind, dkk. 2008). notasi uji statistik F dengan mengikuti notasi yang dinyatakan oleh Ghozali dan Ratmono (2017) dan Gujarati dan Porter (2012), yaitu :

$$
F=\frac{E S S / d f}{R S S / d f}=\frac{E S S /(k-1)}{R S S /(n-k)}
$$

\section{Uji Diagnosik}

\section{Uji Stasioner}

Sebuah data time series dapat dikatakan stasioner apabila rerata dan variasinya tidak bervariasi (konstan) secara sistemik sepanjang waktu (Gujarti dan Porter, 2012). Peneliti menggunakan uji unit root (uji akar unit) untuk menentukan stasioneritas data, yakni menggunakan uji Augmented DickeyFuller Test (ADF Test).

\section{Uji Asumsi}


Uji asumsi klasik yang digunakan dalam regresi linier dengan pendekatan Ordinary Least Squared (OLS) meliputi uji asumsi klasik hanya menggunakan uji multikolinieritas dan uji heteroskedastisitas.

\section{HASIL PENELITIAN DAN PEMBAHASAN}

Hasil tahapan untuk menentukan pemilihan estimasi model data panel dalam penelitian ini dapat dilihat pada tabel 2 di bawah ini:

Tabel 2. Ringkasan hasil uji diagnostik data panel

\begin{tabular}{|l|l|c|l|}
\hline \multicolumn{1}{|c|}{ Uji } & Model & p-value & Keputusan \\
\hline Uji chow & common effect dan fixed effect & 0,000 & Fixed effect \\
Uji Langrange Multiplier & common effects model dan random effects model & 0,000 & Random effect \\
uji Hausman & Random effect dan Fixed effect & 0,0712 & Random effect \\
\hline
\end{tabular}

Sumber : Hasil Olahan Eviews 11

Pada tabel 2 menunjukkan nilai Probabilitas pada Cross section F untuk uji chow kurang dari 0,05 $(0,000<0,05)$ sehingga model yang lebih baik adalah Fixed effect daripada Common effect. Sementara untuk uji Uji Langrange Multiplier menunjukkan nilai probabiltias pada Both kurang dari $0,05(0,000<0,05)$, maka model yang lebih baik adalah Random effect daripada Common effect. Kemudian untuk uji Housman menunjukkan nilai Probabilitas Chi square hitung lebih dari 0,05 $(0,0712>0,05)$ maka model yang lebih baik adalah Random effect daripada Fixed effect. Berdasarkan hasil yang diperoleh pada ketiga uji yang dilakukan untuk menentukan pemilihan estimasi model data panel pada persamaan regresi 1 yang digunakan dalam penelitian ini telah ditentukan adalah menggunakan model Random effect.

Hasil regresi terpilih (Model Random Effect penelitian ini dapat dilihat pada tabel 3 di bawah ini:

Tabel 3 - Ringkasan Hasil Model regresi 1 terpilih: (model random effect)

\begin{tabular}{|l|c|}
\hline & p-value \\
\hline Adjusted R-squared & 0,159 \\
Prob(F-statistic) & 0.0084 \\
Dewan_Direksi_LNX1 & 0.0125 \\
Dewan_Pengawas_LNX2 & 0.5898 \\
Karakteristik_Dewan Direksi_LNX3 & 0.0367 \\
Jumlah_Rapat_LNX4 & 0.2030 \\
\hline
\end{tabular}

Sumber : Hasil Olahan Eviews 11

\section{Pengujian Goodness of Fit Suatu Model Regresi}

Hasil pengujian Goodness of fit model dari uji $\mathrm{F}$ pada tabel 3 didapatkan Nilai F signifikan sebesar 0,0084 dengan taraf signifikan 5\%. Karena nilai Probabilitas pada Nilai F lebih kecil dari $0,05(0,0084<0,05)$ maka model regresi 1 sudah fit. 


\section{Koefisien Determinasi}

Berdasarkan hasil estimasi model random effect pada tabel 5 didapatkan hasil $R$-squared sebesar 0.159684. Nilai ini menunjukkan bahwa model penelitian dapat menjelaskan variabel dependen (Kinerja Keuangan) sebesar 15,96\% sedangkan sisanya sebesar 84,04\% dijelaskan oleh variabel lain diluar model.

\section{Uji Signifikansi Individual atau Uji Statistik t}

Berdasarkan hasil uji t pada Tabel 5 dengan menggunakan tingkat signifikansi $(\alpha)$ sebesar 5\%, maka didapat ada dua variabel yang signifikan yaitu Dewan direksi dengan $t_{\text {hitung }} 0.0125$ dan Karakteristik CEO dengan $t_{\text {hitung }} 0.0367$ (nilai probabilitas kurang dari 0,05).

\section{Uji Signifikansi Simultan atau Uji Statistik F)}

Berdasarkan Tabel 5 terlihat bahwa Prob (F-statistic) memiliki nilai 0,0084 sehingga lebih kecil dibandingkan dengan batas signifikansi sebesar 0,05. oleh karena itu dapat disimpulkan bahwa variabel independen pada model regresi terpilih terbukti secara bersama-sama (simultan) berpengaruh terhadap variabel dependen.

\section{Uji Diagnostik}

\section{Uji Stasioner}

Uji stasioner sebagai uji prasyarat untuk melakukan uji kausalitas pada data time series. Hasil uji stasioner dapat dilihat pada tabel 4 di bawah ini:

Tabel 4 - Hasil Uji Stasioner

\begin{tabular}{llc}
\hline \hline & t-Statistic & Prob.* \\
\hline \hline Augmented Dickey-Fuller test statistic & -5.943974 & 0.0000 \\
\hline \hline
\end{tabular}

*MacKinnon (1996) one-sided p-values.

Sumber : Hasil Olahan Eviews 11

Berdasarkan Tabel 4 terlihat bahwa Augmented Dickey-Fuller Test (ADF Test) memiliki nilai 0.0000 sehingga lebih kecil dibandingkan dengan batas signifikansi sebesar 0,05. Sehingga dapat disimpulkan bahwa tidak terdapat unit root (data stasioner).

\section{Uji Asumsi}

Uji asumsi klasik pada penelitian ini menggunakan pendekatan Ordinary Least Squared (OLS) meliputi uji multikolinieritas dan uji heteroskedastisitas. Adapun hasil Uji asumsi klasik dapat dilihat pada tabel 5 di bawah ini:

Tabel 5 - hasil uji Multikolinearitas dan Heteroskedastisitas

\begin{tabular}{lcc}
\hline \multicolumn{1}{c}{ Variabel } & Uji Multikolinearitas & Uji Heteroskedastisitas \\
\hline Return On Assets (ROA) & & \\
Dewan Direksi & 1.480067 & 0.4652 \\
DPS & 1.415480 & 0.0205 \\
\hline
\end{tabular}




\begin{tabular}{lcc}
\hline Karakteristik Dewan Direksi & 1.634553 & 0.4532 \\
JumlahRapat & 1.245202 & 0.9659 \\
Obs*R-squared & & 0.1237 \\
\hline
\end{tabular}

Sumber : Hasil Olahan Eviews 11

Uji Mulikolinieritas

Berdasarkan Tabel 5 terlihat bahwa Nilai VIF (pada kolom Centered VIF menunjukkan bahwa semua nilai pada masing-masing variabel kurang dari 10). Sehingga dapat disimpulkan bahwa tidak ada masalah multikolinearitas.

Uji Heteroskedastisitas

Berdasarkan Tabel 5 terlihat bahwa Nilai Probabilitas Chi Square pada Obs*R squared sebesar 0,1237 lebih besar dari 0,05. sehingga dapat disimpulkan bahwa uji Heteroskedastisitas pada kedua persamaan regresi di atas tidak ada masalah heteroskedastisitas tidak ada masalah heteroskedastisitas.

\section{Pengujian Hipotesis}

Tabel 6 - Hasil Uji Hipotesis

\begin{tabular}{lcc}
\hline \multicolumn{3}{c}{ Model Random Effect } \\
\hline Variabel & Coefficient & P-Value \\
\hline C & -4.148450 & 0.0116 \\
Dewan Direksi & 2.072588 & 0.0125 \\
DPS & 0.325931 & 0.5898 \\
Karakteristik Dewan Direksi & 0.898866 & 0.0367 \\
JumlahRapat & -0.216257 & 0.2030 \\
\hline R-Squared & \multicolumn{2}{c}{0.159684} \\
F-statistic & \multicolumn{2}{c}{0.008437} \\
\hline
\end{tabular}

Sumber : Hasil Olahan Eviews 11

Berdasarkan tabel 6 dapat dibentuk persamaan regresi 1 terpilih model random effect sebagai berikut:

$$
\operatorname{LnY}_{1}=-4,148+2,072 \operatorname{LnX} 1+0,325 \operatorname{LnX} X_{2}+0,898 \operatorname{LnX}{ }_{3}-0,216 \operatorname{LnX}_{4}
$$

\section{Hipotesis 1}

Nilai p-value yang diperoleh untuk Jumlah Dewan Direksi sebesar 0.0125. Hasil pada penelitian ini menunjukan bahwa hipotesis yang diajukan dapat diterima karena nilai $p$-value $(0.0125)<\alpha 0,05$.

\section{Hipotesis 2}

nilai $\mathrm{p}$-value $<\alpha$ 0,05 maka $\mathrm{H}_{0}$ tidak diterima. Nilai $p$-value yang diperoleh untuk jumlah dewan pengawas syariah sebesar 0,589. Hasil pada penelitian ini menunjukan bahwa hipotesis yang diajukan tidak dapat diterima karena nilai $p$-value $(0,589)>\alpha 0,05$.

Hipotesis 3

Nilai $p$-value yang diperoleh untuk Karakteristik dewan direksi sebesar 0,036. Hasil pada penelitian ini menunjukan bahwa hipotesis yang diajukan dapat diterima karena nilai $p$-value $(0,036)<\alpha 0,05$.

Hipotesis 4 
Nilai $p$-value yang diperoleh untuk Jumlah Rapat Dewan sebesar 0,203. Hasil pada penelitian ini menunjukan bahwa hipotesis yang diajukan tidak dapat diterima karena nilai $p$-value $(0,203)>\alpha 0,05$.

\section{PEMBAHASAN}

Hasil pengujian hipotesis pertama pada persamaan regresi dapat diterima karena nilai $p$-value yang diperoleh untuk Jumlah Dewan Direksi sebesar $0.0125<\alpha 0,05$ pada taraf $\alpha=5 \%$. Koefisien regresi dari variabel $\mathrm{X}_{1}$ yakni jumlah dewan direksi adalah sebesar 2,072. Artinya semakin tinggi jumlah dewan direksi pada Bank umum syariah maka kinerja keuangan akan semakin meningkat. Hasil ini mendukung teori keagenan yang menjelaskan bahwa Direksi sebagai pihak yang bertanggungjawab penuh atas pengelolaan perusahaan lebih banyak kesempatan untuk berperilaku oportunistik maka dengan ukuran dewan yang optimal meningkatkan pemantauan untuk meningkatkan kinerja perusahaan. Hasil pengujian ini sejalan dengan hasil penemuan peneliti sebelumnya yaitu Gafoor, dkk., (2015), Haider, dkk. (2015), Isik dan ince (2016), Kalsie dan Shrivastav (2016), Badu dan Appiah (2016), Belhaj dan Mateus (2016), Shunu, dkk (2017) dan Younas dan Ahmed (2018) yang menemukan hasil bahwa dewan direksi berpengaruh terhadap kinerja keuangan.

Hasil pada penelitian ini menunjukan bahwa hipotesis yang diajukan pada persamaan regresi dapat diterima karena nilai $p$-value $(0,036)<\alpha 0,05$. Koefesien regresi variabel $\mathrm{X}_{3}$ diperoleh sebesar positif 0,898 Artinya semakin tinggi karakteristik dewan direksi maka kinerja keuangan pada Bank Umum Syariah akan semakin bertambah. Hasil pengujian ini sejalan dengan hasil penemuan peneliti sebelumnya yaitu Cardillo dkk, 2020, Low, dkk (2015), Belhaj dan Mateus (2016), Ahmadi dkk (2017), Conyon (2017) dan Dang, dkk (2020) yang menemukan hasil bahwa karakteristik dewan direksi yang diukur dengan Keragaman gender juga berhubungan positif dengan kinerja.

\section{KESIMPULAN}

Hasil penelitian menunjukkan bahwa jumlah dewan direksi dan karakteristik dewan direksi berpengaruh positif terhadap kinerja keuangan pada Bank umum syariah. Sementara Jumlah dewan pengawas syariah dan jumlah rapat dewan direksi tidak memiliki pengaruh terhadap kinerja keuangan. Penelitian ini dapat digunakan sebagai landasan bagi peneliti selanjutnya yang ingin mendalami lebih dalam tentang tata kelola perusahaan pada sektor perbankan Indonesia. Penelitian ini memiliki sejumlah keterbatasan terkait ketersediaan data untuk bank penelitian ini hanya menggunakan 12 bank Umum Syariah sebagai sampel untuk jangka waktu lima tahun dari tahun 2014 hingga 2018. Hal ini menyebabkan sulitnya melakukan analisis ekstra pada sektor perbankan Syariah Indonesia. Penelitian selanjutnya dapat menggunakan sampel data yang lebih besar bersama 
dengan periode sampel yang lebih lama untuk menawarkan pemahaman yang lebih baik tentang tata kelola perusahaan.

\section{Daftar Pusataka}

Almuatairi, Ali R, Quttainah, M.A. (2017). Corporate governance: evidence from Islamic banks", Social Responsibility Journal, https://doi.org/10.1108/SRJ-05-2016-0061

Ahmadi, Ali,. Nakaa, N dan Bouri, A. (2017). Chief Executive Officer attributes, board structures, gender diversity and firm performance among French CAC 40 listed firms. Research in International Business and Finance 44 (2018) 218226

Ajili, H. dan A. Bouri. (2018). Corporate governance quality of Islamic banks: measurement and effects on financial performance. International Journal of Islamic and Middle Eastern Finance and Management 11 (3) : 470-487

Aribi, Z.I., Arun, T.,Gao, S. (2018). Accountability in Islamic financial institution: the role of the Shari'ah supervisory board reports", Journal of Islamic Accounting and Business Research, https://doi.org/10.1108/JIABR-10-2015-0049

Atrill, P dan McLaney, E. (2006). Accounting And Finance For Non Specialists. Prentice Hall

Aziz, R. A., A. Abdul-Rahman \& R. Markom. (2019). Best Practices for Internal Shariah Governance Framework: Lessons from Malaysian Islamic Banks. Asian Journal of Accounting and Governance 12: 37-49

Badu, E.A dan Appiah, K.O. (2017). The Impact of Corporate Board Size on Firm Performance: Evidence from Ghana and Nigeria. Research in Business and Management2017, Vol. 4, No. 2

Baltagi, B.H. (2005). Econometric analysis of panel data - 3rd ed. John Wiley \& Sons Ltd. West Sussex. England

Bhatt, P. R. dan R. Bhatt. (2017). Corporate governance and firm performance in Malaysia. Corporate Governance: The International Journal of Business in Society 17 (5) :896 - 912.

Beg, S. (2016). Prospects, Problems and Potential of Islamic Banking in India .International Journal of Accounting and Financial Management Research 6 (3) :

Belhaj, S dan Mateus, C. (2016). Corporate governance impact on bank performance evidence from Europe. Corporate Ownership \& Control. Volume 13, Issue 4, Summer 2016.

Buallay, A. (2019). Corporate governance, Sharia'ah governance and performance A cross-country comparison in MENA region. International Journal of Islamic and Middle Eastern Finance and Management 12 (2) : 216-235

Buchdadi, A. D., G. K. A. Ulupui, S. Dalimunthe, B. G. Pamungkas dan Y. Fauziyyah. (2019). Board of Director Meeting and Firm Performance. Academy of Accounting and Financial Studies Journal 23 (2) : $1-7$ 
Bukair, A.A. dan A. A. Rahman. (2015). Bank performance and board of directors attributes by Islamic banks. International Journal of Islamic and Middle Eastern Finance and Management 8 (3) : 291-309

Cardillo, G., Onali, E dan Torluccio, G. (2020). Journal of Corporate Finance, https:/doi.org/ 10.1016/j.jcorpfin. 2020.101560

Conyon, Martin J dan He, Lerong. (2017). Firm performance and boardroom gender diversity: A quantile regression approach. Journal of Business Research (2017), http://dx.doi.org/ 10.1016/j.jbusres.2017.02.006

Dang, R., Houanti, L'Hocine., Reddy, K., Simioni, M. (2020). Does board gender diversity influence firm profitability? A control function approach. Economic Modelling (2020), doi: https:// doi.org/10.1016/j. econmod. 2020.05.009.

Daoud, Khaleel, I.A,. Saidin, S.Z., Abidin, S. (2016). board meeting and firm performance: evidence from the amman stock exchange. Corporate Board: Role, Duties \& Composition / Volume 12, Issue 2, 2016

Darwanto dan Chariri, Anis. (2019). Corporate governance and financial performance in Islamic banks: the role of the sharia supervisory board in multiple-layer management. Banks and Bank Systems, Volume 14, Issue 4, 2019.

Eluyela, D. F., O. O. Akintimehin, W. Okere, E. Ozordi, G. O. Osuma, S. O. Ilogho dan O. A. Oladipo. (2018). Board meeting frequency and firm performance: Examining the nexus in Nigerian deposit money banks. Heliyon 4 (10) : $1-14$

Farag, H., Mallin, C, Yong, K.O. (2017). Corporate Governance in Islamic Banks: New Insights for Dual Board Structure and Agency Relationships. Journal of International Financial Markets Institutions and Money, August 2017

Ghozali, I dan Ratmono, D. (2017). Analisis Multivariat dan Ekonometrika : Teori, Konsep dan Aplikasi dengan Eviews 10 Edisi 2. Badan Penerbit Undip. Semarang

Grassa, R. (2013). Shariah supervisory system in Islamic financial institutions New issues and challenges: a comparative analysis between Southeast Asia models and GCC models. Humanomics 29 (4) : 333-348

Grassa, R. (2016). Corporate governance and credit rating in Islamic banks: Does Shariah governance matters?. Journal of Management \& Governance 20 : 875-906Gafoor, C.P. Abdul., Mariappan, V., Thyagarajan, S. 2015. Board characteristics and bank performance in India. IIMB Management Review (2018) 30, 160-167

Greene, W. H. (2003). Econometric Analysis : Fifth Edition. Pearson Education, Inc. Upper Saddle River. New Jersey

Gujarati, D. N dan D. C. Porter. (2012). Dasar - Dasar Ekonometrika. Buku 1 dan 2. Edisi 5. Salemba Empat: Jakarta 
Haider, N, Khan N., Iqbal N. (2015). Impact of corporate Governance on Firm Financial Performance in Islamic Financial Institutional. International Letters of Social and Humanistic Sciences. ISSN: 2300-2697, Vol. 51, pp 106-110.

Hashem, B. dan H. Sujud. (2019). Financial performance of banks in lebanon : conventional vs islamic. International business research $12(2): 40-51$

Hassan, M.K., dan S.S. Halbaouni. (2013). Corporate governance, economic turbulence and financial performance of UAE listed firms. Studies in Economics and Finance 30(2): 118-138

Hassan, M., M. Rizwan dan H. M. Sohail. (2017). Corporate Governance, Shariah Advisory Boards and Islamic Banks' Performance. Pakistan Journal of Research $18: 173-184$

Juanda, A., F. D. Herlyanto dan T. W. Oktavendi. (2019). The Implementation of Good Governance Business Shariah in Indonesia Shariah Banking. 2nd ICIEBP The 2nd International Conference on Islamic Economics, Business, and Philanthropy (ICIEBP) Theme : "Sustainability and Socio Economic Growth" Volume 2019

Kalsie, Anjala dan Shrivastav, Shikha Mittal. (2016). Analysis of Board Size and Firm Performance: Evidence from NSE Companies Using Panel Data Approach. Indian Journal of Corporate Governance 9(2) 148-172

Kowalewski, O. (2016). Corporate governance and corporate performance: financial crisis(2008). Management Research Review 39 (11) : 1494 - 1515.

Kusuma, H. (2019). Sri Mulyani : Industri Syariah Kita Sangat Tertinggal. Detik Finance. https://finance.detik.com/berita-ekonomi-bisnis. Jumat, 23 Agustus 2019

Lind, D. A., W. G. Marchal dan S. A. Wathen. (2008). Teknik - Teknik Statistika dalam Bisnis dan Ekonomi Menggunakan Kelompok Data Global. Salemba Empat. Jakarta

Low, Daniel C.M., Roberts, H dan Whiting, R.H. (2015). Board gender diversity and firm performance: Empirical evidence fromHong Kong, South Korea, Malaysia and Singapore. Pacific-Basin Finance Journal (2015), http://dx.doi.org/10.1016/j.pacfin.2015.02.008

Maradita, A. (2014). Karakteristik Good Corporate Governance Pada Bank Syariah Dan Bank Konvensional. Yuridika 29 (2) : 191-204

Masruki, R., M. M. Hanefah dan N. A. Wahab. (2018). International Journal of Engineering \& Technology, 7 (3.25) : 710-714

Mishra, R.K dan Kapil, S. (2018). Effect of board characteristics on firm value: evidence from India. South Asian Journal of Business Studies, https://doi.org/10.1108/SAJBS-08-2016-0073

Mizushima, T. (2014). Corporate Governance and Shariah Governance at Islamic Financial Institutions: Assessing from Current Practice in Malaysia. Reitaku Journal of Interdisciplinary Studies 22 (1) : 59 - 84. 
Mohammad, S. J., M. Abdullatif dan F. Zakzouk. (2018). The Effects Of Gender Diversity On The Financial Performance Of Jordanian Banks. Academy of Accounting and Financial Studies Journal $22(2): 1$ - 11

Nastiti, A.S. dan A. I. Firdaus. (2019). Menuju Tiga Dekade Perkembangan Perbankan Syariah di Indonesia. Jurnal Ilmiah Akuntansi Indonesia 4 (2) : 135 - 147

Nomran, N.M., R. Haron dan R. Hassan. (2018). Shari'ah supervisory board characteristics effectss on Islamic banks' performance: Evidence from Malaysia. International Journal of Bank Marketing 36 (2) : 290-304.

Qadorah, A.A. M. dan Fadzil, F. H. Bt. (2018). The Effect of Board Independence and Board Meeting on Firm Performance: Evidence from Jordan. Journal of Finance and Accounting 2018; 6(5): 105-109

Shunu, A. H., Bii, P dan Ombaba, K. M. (2017). the effect of board size on firm financial performance of listed firms in nairobi security exchange. European Journal of Business, Economics and Accountancy. Vol. 5, No. 6, 2017

Sriyana, J. (2014). Metode Regresi Data Panel. Ekonisia. Kampus FE UII. Yogyakarta

Subramanyam, K. R. (2014). Financial statement analysis : Eleventh edition. McGraw-Hill Education. New York.

Ullah, M. dan R. Khanam. (2018). Whether Shari'ah compliance efficiency is a matter for the financial performance : The case of Islami Bank Bangladesh Limited. Journal of Islamic Accounting and Business Research 9 (2) : 183-200

Usman, sabo. (2018). Corporate Board Meeting Frequency and Financial Performance of Listed Building Materials Companies in Nigeria. International Journal of Research and Innovation in Social Science (IJRISS) |Volume II, Issue V, May 2018

Valenti, M.A., R. Luce, dan C. Mayfield. (2011). The effectss of firm performance on corporate governance. Management Research Review 34(3): 266-283

Wahab, A. H. A. dan R. Haron, (2017), Efficiency of Qatari banking industry: an empirical investigation. International Journal of Bank Marketing 35 (2) : 298-318.

Younas, M., U. Ahmed dan Naveed. (2018). Impact Of Corporate Governance Of Islamic Banks On Financial Performance: A Study Of Pakistan, India And Bangladesh Islamic Banking System. Iqra Journal of Business \& Management (IJBM) 2 (1) : 11-22

Zabri, S.M., Ahmad, K,. Wah, K.K. (2016). Corporate Governance Practices and Firm Performance: Evidence from Top 100 Public Listed Companies in Malaysia. Procedia Economics and Finance 35 ( 2016 ) $287-296$ 